Global Conferences Series:

Social Sciences, Education and Humanities (GCSSSEH), Volume 3, 2019

The $1^{\text {st }}$ International Conference on Education, Social Sciences and Humanities

DOI: https://doi.org/10.326/hum0207

\title{
Eco-pedagogy on Senior High School: A Proposal for Ecological Issues in Teaching Sociology
}

\section{Poerwanti Hadi Pratiwi}

Universitas Negeri Yogyakarta, Indonesia

ph_pratiwi@uny.ac.id

\begin{abstract}
In the industrial revolution 4.0, global media is powerful agent that can be used to develop an ideology that ecological devastation is necessary - hiding interconnections between environmental and socio-cultural problems. This article proposed ecopedagogy is alternative educational approach that requires analysis of critical media, to determine ecological and social injustices that could be reversed to solve problems, as well as to promote democracy, more effective social movements, and assist in the political struggles of all people. Using the public sociology lens, this article explored how ecological issues constructed as public issue through eco-pedagogy within the processes of teaching and learning in high school sociology. This qualitative research supported by the content analysis technique. The sample includes the handbook of education for sustainable development in Indonesia, the Ministerial Regulation about implementation of the green-school or 'Adiwiyata' school, the development guidelines of environmental education content, and four documents curriculum of the high school sociology. This research found that the eco-pedagogues and their students must dialectically view socio-environmental devastation from the local and the global to understand complex socio-environmental oppressor/oppressed relationships. Among the most important findings is needed a model of teaching sociology that rooted on ecopedagogy for developing students' ecological intelligent.
\end{abstract}

Keywords: eco-pedagogy, ecological issues, public sociology, secondary high school, teaching sociology

\section{Introduction}

Today's threats demand that we hone a new sensibility, the global economy growth attacked on all fronts - the oceans, the land, water, the atmosphere - the earth's systems are breaking down. In this context, socio-ecological sustainability must be the highest priority for human civilizations, and through examining and critiquing unsustainable social systems, we can - and must - set some guideposts for current and future action toward sustainability. Within this context, the pedagogical approaches needed for the development of an ecological consciousness and a planetary citizenship. The pedagogic settings in this article are all inspired by a vision about the purposes of schooling,

Copyright (C) 2019, the Authors. Published by Redwhite Press.

Page | 127

This is an open access article under the CC BY-NC license (http://creativecommons.org/licenses/by-nc/4.0). 
promoting a deep and explicit re-conceptualization of what human beings are capable of achieving. Taking a critical-transformative approach to pedagogic settings - be they secondary school classrooms - ask a great deal of those who embrace the challenge. In this context, schools require a transformation of the educational vision, or as proposed by Gadotti (2010, p. 205), 'the need of an ecopedagogy, namely a pedagogy appropriate to education practices based on sustainability'. It's an academics and praxis movement that represents Freire's critical pedagogy (2005). Eco-pedagogy introduce 'big ideas' that help to frame the way we look at learning and teaching in new ways learners can be empowered to move out of a culture of 'silence' by learning to 'read the world', especially for ecological issues.

This paper proposed eco-pedagogy approach in high school sociology through ecological issues as content course. In the digital era, sustainable innovation is needed. Eco-pedagogy, as part of the critical pedagogy, is going to take centre stage in sustainable innovation in the digital era. Moreover, it is important to promote the social transformations on sustainable culture (Desha \& Hargroves, 2014; Nikolopoulou, Abraham, \& Mirbagheri, 2010). Educators around the world are clearly grappling with sustainability-related terminology and concepts (Elbaar \& Limantara, 2019; Arnawa, Sukerta, \& Limantara, 2018; Rajaraman \& Thiruvenkatasamy, 2013) and creating of sustainable education practices that are integrated into and relevant to the needs and practices of the larger world (Srikongphlee, Luvila, \& Kanato, 2018; Thorpe, 2018). Through a content analysis in this research, ecopedagogy should not be seen as a theoretical perspective but as a pedagogical approach in teaching and learning high school sociology.

The challenge of teaching high school sociology to include sustainable innovation in the digital era is complex. Generally, what is the sociological context of pedagogical decisions and practices? What influences sociology teachers' decisions about course goals and content? How and why have content and objectives, and the course-related outcomes they produce, changed over time - especially in the digital era? What are the historical, intellectual, and organizational forces that have acted to shape the content and objectives of the high school sociology? This paper answers these questions through an examination of high school sociology courses. Discussions in this paper focus on a list of course goals, the sociological content and context for pedagogical practices, a review of relevant pedagogical approach, and a clear description of pedagogical techniques and possible improvements to them.

\section{Ecopedagogy, Ecological Issues, and Public Sociology: Pathways for High School Sociology}

Growing out of the intellectual and praxis work of Paulo Freire, ecopedagogy is a growing scholarly field that applies basic principles of critical pedagogy to the study of intersecting social and ecological issues (Martusewicz, Edmundson, \& Lupinacci, 2011). Kahn (2010) interprets ecopedagogy as a development of critical pedagogy which inspired educators like Paulo Freire to see that a critical pedagogy must cultivate an ecological dimension. Antunes \& Gadotti (2005) points out that:

Eco-pedagogy is not just another pedagogy among many other pedagogies. It not only has meaning as an alternative global project concerned with nature preservation (Natural Ecology) and the impact made by human societies on the natural environment (Social Ecology), but also as a new model for sustainable civilization from the ecological point of view (Integral Ecology), which implies making changes on economic, social, and cultural structures. ... (p. 136).

Ecopedagogy as a form of critical theory of education, working on meta level - to offer criticism dialectic environmental education and education for sustainable development as a form of hegemony of the discourse of education which has been created by the agency countries that seek to develop pedagogy relevant to reduce the global warming crisis in ecology (McLaren, 2013; Norat, Herreria, \& Rodriguez, 2016). As a movement with the approach of the education, ecopedagogy always open to criticism from educational praxis. Ecopedagogy as critical pedagogy have a place in the curriculum as an educational praxis. In particular, Freire (2005) explains that: 
I do not believe in loving among women and men, among human beings, if we do not become capable of loving the world. Ecology has gained tremendous importance at the end of this century. It must be present in any educational practice of a radical, critical, and liberating nature ( $p .25)$.

Ecopedagogy, a deep alternative to shallow models, focuses on ending/decreasing social oppressions by critically learning how and why environmental problems are both the causes and effects of social conflicts. Ecopedagogy is plural in definition and in essence critical and dialectical (Kahn, 2010). Ecopedagogy allows for individual and social transformation by critically questioning what is being taught and why (Freire, 2005; Mezirow, 1991). Critical, horizontal dialogue is essential for ecopedagogues to be able to democratically construct possible alternatives to oppressive systems, a process that moves toward utopian social justice teaching models (Gadotti, 2010). Student(s) and teacher(s) teach and learn together to determine the results of and incentives for environmental devastation - especially in formal education. Misiaszek (2011) suggest the lenses of theoretical to construct effective ecopedagogy, to deconstruct current ecopedagogy, and to create pedagogical tools for teachers.

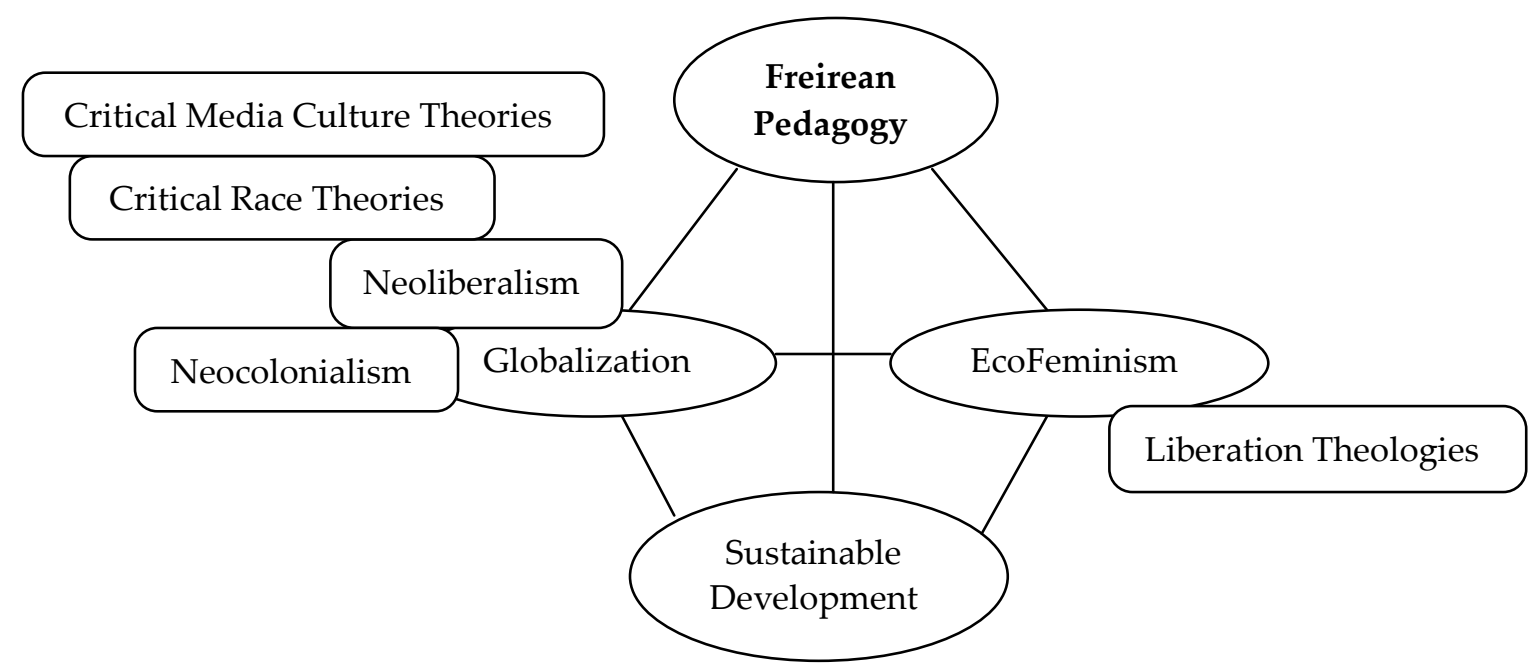

Figure 1. The main components of the Freirean Pedagogy to build ecopedagogy model

(Source: Misiaszek, 2011: 223)

Although there are interconnections between all the theories represented in the model, it was found that the essence of Freirean Pedagogy must be foundational in the teaching. Freirean pedagogy emerged as the central pedagogical element for ecopedagogy to be successful since it promotes teaching that is 1) transformative and 2) democratic. Furthermore, Misiaszek (2011) stated that transformative as the first Freirean element, enables ecopedagogues engage in radical discourse in the sense that they believe the goal of education is to transform current forms of oppression within social, economic, and political systems. Without hope for transformation, ecopedagogy just becomes a tool of oppression rather than a tool to educate for empowerment. The second Freirean element of democratic education is that the students control their own learning and determine what they need to know and how they will learn it. Horizontal dialogue-the opposite of banking education- is essential if students are to make meaning of what they are being taught. Students construct this meaning by comparing and contrasting their socio-environmental knowledge with those of other students and the teacher(s). Freire's democratic education model also allows for commonalities to emerge, an essential element of empowering social justice education that the participants identified.

In relation with this research, a school subject could be used to promote environmental awareness and understanding through integration of ecological issues on content course. Hayward (2012) stated 
how even children in the primary years can be taught to both understand and act on sound principles related to environmental and social concern. Furthermore, a project conducted by the European Commission showed that schools, especially through the development of special skills academies, can play a role in developing 'green skills' for a changing economy (ECORYS, 2010). Finally, Kennedy \& Chow (2013) concluded that the role of schools in developing understanding of the environment as a key citizenship value that has the potential to influence not just attitudes but knowledge and actions as well.

The challenge of teaching high school sociology to include sustainable innovation in the digital era is complex. New forms of knowledge would emerge to bring intellectual expertise together with experiential learning, and new technologies and forms of best practices that could be networked from the bottom-up. In the secondary schools, sustainable innovation could motivate by growing human and social awareness - by social "science". Take, for example, sociology, the range of topics is almost limitless - from community development movement to energy efficiency, from local community's wisdom to holistic health. Conversations about curricular planning begin with the discussion of the ecological issues theme. What is the theme for this sociology classes, and how will our courses or disciplines come together around this theme? What are the intended outcomes for students? Atkinson \& Lowney (2016) illustrates the goals and student learning outcomes in sociology courses.
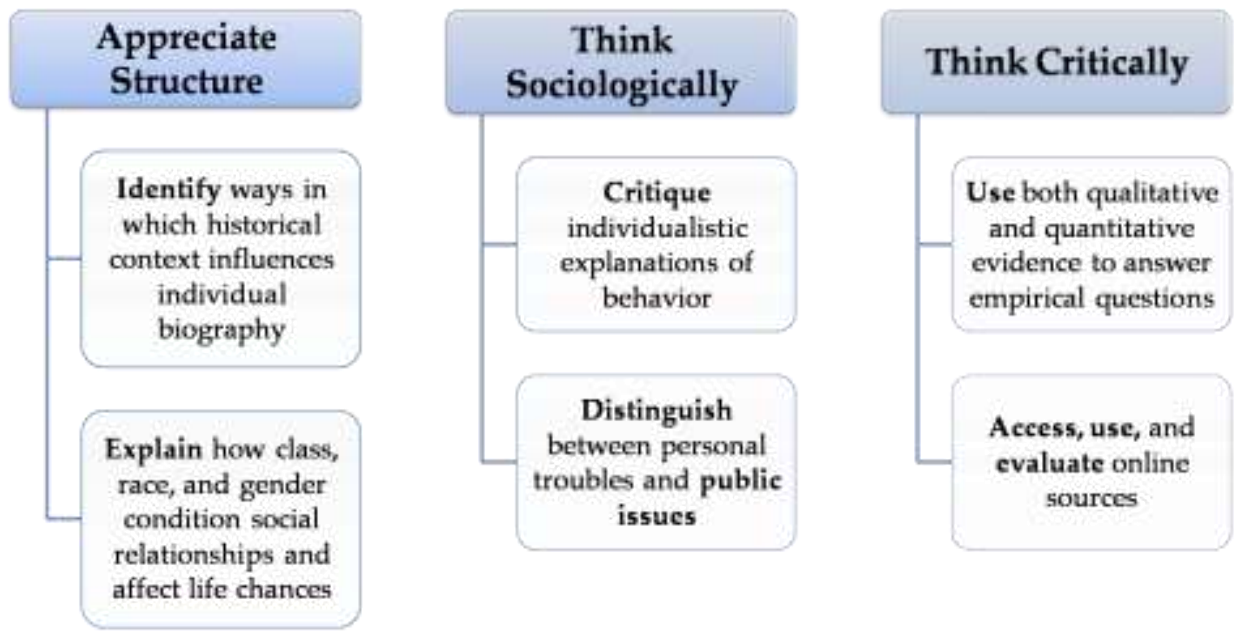

Figure 2. Goals and Student Learning Outcomes Source: Atkinson \& Lowney (2016: 7)

According Figure 2, Atkinson \& Lowney determine two goals that focus on the discipline: 'appreciate structure' and 'think sociologically', whereas 'think critically', as third goal that is more generally shared across many disciplines. Student learning outcomes could be seen from each goals description. Example, educators could use 'think sociologically' through public issues in teaching and learning. Public Sociology endeavors to bring sociology into dialogue with audiences beyond the academy, an open dialogue in which both sides deepen their understanding of public issues (Burawoy, 2005). Public sociology, a dialogue between sociologists and publics regarding sociological knowledge and understandings (Jeffries, 2009; Hartmann, 2016) and it has become a considerable amount of intra-disciplinary discussion (Gans, 2016).

Using public sociology lens because high school students would grow up to be politicians, social practitioners of a wide variety, and members of the media with whom we are intent on communicating (Atkinson, 2000). For this reasons, a few sociologists have drawn a direct link 
between the improvement of high school sociology and the improvement of the discipline's public image (Watson, 1955; Seperson, 1994; DeCesare, 2007). Furthermore, Robert \& Piker-King (1995: 3) also pointed out that, "if high school educators are conveying accurately what sociological knowledge is and what its value is, our discipline is further along in shaping a favorable public opinion". Finally, Burawoy (2013) stated that "public sociology is a form of teaching in which common sense is cultivated and society itself becomes a classroom, a classroom for developing a critical social consciousness that strives for what could be rather than adapting to what is" (p. 297). Based on the reasons above, this article explored how ecological issues constructed as public issue through ecopedagogy within the process of teaching and learning in high school sociology.

\section{Method}

This research applied content analysis approach which proposed by Krippendorff (2013) and Neuendorf \& Kumar (2015) to explored how ecological issues constructed as public issue through eco-pedagogy within the process of teaching and learning in high school sociology. Krippendorf (2013: 24) defined content analysis as "a research technique for making replicable and valid inferences from texts (or other meaningful matter) to the contexts of their use". In this study, the steps of content analysis: (1) identify some documents related to the purpose of the research, (2) selects document samples to be analyzed, (3) develops a procedure of category-coding, (4) do a content analysis, and (5) interprets the results.

The qualitative approach use to analyze the document samples, include: (1) the handbook of education for sustainable development in Indonesia, (2) the Ministerial Regulation about implementation of the green-school or 'Adiwiyata' school, (3) the development guidelines of environmental education content, and (4) four documents curriculum of the high school sociology. Schreier (2012) identifies the features of qualitative content analysis as interpretive, naturalistic, situational, reflection, having emergent flexibility, inductive, case-oriented, and putting emphasis on validity. As a part of this process, the researcher identifies thematic patterns in a text (i.e., message or set of messages). The themes are not imposed upon the text from outside (e.g., via a theoretically informed coding scheme) or a priori, but they emerge as the researcher undertakes a close reading of a text. Once themes are identified the analyst looks for thematic patterns in the text. In this research, the findings were triangulated through different sources and review from experts.

\section{Results and Discussion}

Freirean Pedagogy emerged as the theoretical foundation of effective ecopedagogy from this research. Freirean Ecopedagogy focuses on the conscientização of societal oppression through the critical discourse over ecological issues, such as globalization, neoliberalism, the hidden curricula, and the significance of the ideology of global/local. Those issues should be part of the curriculum in the schools. A key tenet of Freire's concept of praxis was a belief that the coding and re-coding of theory was essential for theory to become and remain relevant. Ecological issues must be deconstructed and re-constructed within social justice frameworks, employing critical dialogue, to enhance humans' "reading of the world" through various knowledge and theoretical framework. This paper proposed eco-pedagogy approach in high school sociology through ecological issues as content sociology course. Discussions in this paper include: (i) student learning outcomes of sociology course in Indonesian high schools, (ii) dimension of ecopedagogy and ecological issues in sociology course, and (iii) description of pedagogical techniques on teaching ecological issues.

\section{Student Learning Outcomes of Sociology Course in Indonesian High Schools}

Based on document curriculum of schooling in Indonesia, since the 1994, sociology as a subject has been taught at the secondary high school level. After doing content analysis, student learning outcomes of sociology course in Indonesian high schools have changes followed the dynamics of 
social changes in Indonesian country. Analysis results for student learning outcomes of sociology course in Indonesian high schools can be seen in Table 1 below.

Curriculums have specific purposes, and these are most often not shared with students. Those purposes are sometimes determined by vigorous public debate, but often they are hidden in assumptions about who students are and about how the world works. The "hidden curriculum" (Giroux, 1988), is the unstated norms, values, and beliefs that are transmitted to students through the underlying structure of meaning and in both the formal content the social relations of school and classroom life. Even more, they will have to recognize the function of hidden curriculum and its capacity for undermining the goals of social education. For instance, Apple (2004) argues that "schools do not only control people; they also help control meaning. Since they preserve and distribute what is perceived to be "legitimate knowledge" - the knowledge that "we all must have," schools confer cultural legitimacy on the knowledge of specific groups" (p. 61). If educators such as Apple and Giroux are correct, and we think they are, therefore social studies developers will have to build their pedagogical models upon a theoretical framework which situates schools within a sociopolitical context.

Table 1. Student Learning Outcomes of Sociology Course in Indonesian High Schools

\begin{tabular}{|c|c|}
\hline Curriculum & Student Learning Outcomes \\
\hline $\begin{array}{l}\text { The } 1994 \\
\text { Curriculum }\end{array}$ & $\begin{array}{l}\text { Developing the attitude and behavior of students who are rational and } \\
\text { critical in the face of differences in society, cultural differences and social } \\
\text { situations, as well as various of socio-cultural problems encountered in } \\
\text { everyday life }\end{array}$ \\
\hline $\begin{array}{l}\text { The } 2004 \\
\text { Curriculum } \\
\text { (Curriculum } \\
\text { based- competence } \\
\text { or KBK) }\end{array}$ & $\begin{array}{l}\text { a. cognitively, aims to provide basic knowledge of Sociology so that } \\
\text { students are able to understand and examines rationally the } \\
\text { components of the individual, culture and society as a system } \\
\text { b. practically, aims to develop the skills of the attitude and behavior of } \\
\text { students who are rational and critical in the face of multicultural } \\
\text { society, culture, social situation as well as various social problems } \\
\text { found in everyday life }\end{array}$ \\
\hline $\begin{array}{l}\text { The } 2006 \\
\text { Curriculum } \\
\text { (School-based } \\
\text { Curriculum or } \\
\text { KTSP) }\end{array}$ & $\begin{array}{l}\text { a. Understanding the concepts of Sociology such as socialization, social } \\
\text { groups, social structure, social institutions, social change, and the } \\
\text { conflict up to the creation of social integration } \\
\text { b. Understanding the various of social roles in the society life } \\
\text { c. Fostering the attitude, awareness and social care in the life of society }\end{array}$ \\
\hline $\begin{array}{l}\text { The } 2013 \\
\text { Curriculum }\end{array}$ & $\begin{array}{l}\text { a. Increasing mastery of knowledge Sociology among learners-oriented } \\
\text { problem solving and social empowerment } \\
\text { b. Develop knowledge of sociology in practice or the practice of } \\
\text { Sociology knowledge to improve social skills of learners in the social } \\
\text { problems solving } \\
\text { c. Cultivate an attitude of religious and social ethics is high among } \\
\text { learners for having the awareness, caring, and the responsibility of the } \\
\text { social problems solving }\end{array}$ \\
\hline
\end{tabular}

This research has found some of hidden meaning from the curriculum structure of high school sociology. Teacher can teach students to achieve messages through learning outcomes. But not all learning occurs in the classroom. When developing the high school sociology curriculum for the ecological issues, consider students' entire learning experiences and not only opportunities for learning within the classroom. Consider experiential learning activities, service projects, internships, 
RedWhitepress Global Conferences Series: Social Sciences, Education and Humanities (GCSSSEH), Volume 3, 2019

field trips, or school activities that might deepen students' understanding of course and sustainability concepts.

\section{Dimension of Ecopedagogy and Ecological Issues in Sociology Course}

Where, when and how such an imaginative transformation will take hold is an open question. It already exists in varying degrees, in this study on secondary school level. The green schools or 'Adiwiyata', it is a proposal to create an overarching "school of integrated planning and sustainability" that could bring the academic curriculum together with teachers and students, the imaginative planning with operational practicality. This type of proposal is simple, with integrating ecological issues on content course. Its impact would be more seen because it is a first step to creating the new dynamics for systemic change. Such proposals should be at the top of the agenda of every school, a necessary first step in creating a planetary school.

Overall, the findings make evident that dimension of ecopedagogy could understood and established on sociology course - see Table 2. The author using public sociology lens for explored ecological issues. 
Table 2. Dimension of Ecopedagogy and Ecological Issues in Sociology Course

\begin{tabular}{|c|c|}
\hline Dimension of Ecopedagogy & Ecological Issues in Sociology Course \\
\hline $\begin{array}{l}\text { The head, learning to know } \\
\text { - Approach issues and situations from a } \\
\text { systems perspective } \\
\text { - Understand fundamental ecological } \\
\text { principles } \\
\text { - Think critically, solve problems } \\
\text { creatively, and apply knowledge to } \\
\text { new situations } \\
\text { - Assess the impacts and ethical effects } \\
\text { of human technologies and actions } \\
\text { - Envision the long-term consequences } \\
\text { of decisions } \\
\text { The heart, learning to be } \\
\text { - Feel concern, empathy, and respect for } \\
\text { other people and living things } \\
\text { - See from and appreciate multiple } \\
\text { perspectives; work with and value } \\
\text { others with different backgrounds, } \\
\text { motivations, and intentions } \\
\text { - Commit to equity, justice, inclusivity, } \\
\text { and respect for all people } \\
\text { The hands, learning to do } \\
\text { - Create and use tools, objects, and } \\
\text { procedures required by sustainable } \\
\text { communities } \\
\text { - Turn convictions into practical and } \\
\text { effective action, and apply ecological } \\
\text { knowledge to the practice of } \\
\text { ecological design } \\
\text { - Assess and adjust uses of energy and } \\
\text { resources } \\
\text { The spirit, learning to live together } \\
\text { - Experience wonder and awe toward } \\
\text { nature } \\
\text { - Revere the Earth and all living things } \\
\text { - Feel a strong bond with and deep } \\
\text { appreciation of place } \\
\text { - Feel kinship with the natural world } \\
\text { and invoke that feeling in others }\end{array}$ & $\begin{array}{l}\text { - The cosmology of ecology from traditional } \\
\text { - The impact of the industrial revolution on the } \\
\text { current environment } \\
\text { - Consumer behavior-based natural resources } \\
\text { - The capitalist hegemony over the consumer society } \\
\text { - Neoliberalism and its impact to the environment } \\
\text { - Sustainable development } \\
\text { - Great narrative about the human position as ruler } \\
\text { of nature } \\
\text { - The exploitation of natural resources for industrial } \\
\text { - The buildup of capital-driven results of the } \\
\text { exploitation of natural resources } \\
\text { - Local wisdom in maintaining environmental } \\
\text { sustainability } \\
\text { - Observing people's lives along the river in the } \\
\text { urban and rural setting } \\
\text { - Empowerment of local communities } \\
\text { - The movement to resist of foreign powers that } \\
\text { - Tamage on environment } \\
\text { - Independence from dominant ideologies of } \\
\text { - Independence from the negative impact of } \\
\text { industrialization } \\
\text { - Independence from the imbalance of access to } \\
\text { natural resources are available in the local } \\
\text { environment } \\
\text { - Independence from pollution } \\
\text { - The human's adaptability to the nature } \\
\text { environment } \\
\text { - The exploitation of natural resources and the } \\
\text { consumer prources in colonized community } \\
\text { ekosentrism }\end{array}$ \\
\hline
\end{tabular}

Developing of the sociological literacy is another aim from the ecological issues within learning sociology for high school students. Students write reflection papers in response to the assigned readings and relate issues in the readings to their experiences at the community sites. At their community sites, students take field notes based on their observations of ecological issues. The major assignment for the course is a research paper studying ecological issues that involves their immediate 
community. The written reports include a statement of the problem, the objectives of the study, a brief overview of previous research, and analysis and interpretation of data (personal interview(s) and field notes).

\section{Description of Pedagogical Techniques on Teaching Ecological Issues}

Students have a right to know what kinds of learning goals teacher set for them, why those goals were chosen and not others, and how teacher will be measuring their learning. "Think of the goals and outcomes as how the travelers on the sociological journey (your students and you) will measure whether the trip was a success" (Atkinson \& Lowney, 2016, p. 19). Curriculum that is developed based on ecopedagogy would be closely related to the problem-posing methods of learning. That is, problem-posing could be used as the methods of learning for an educational system oriented towards achieving solutions for existing ecological problems and prevention of the future. Scenario of teaching ecological issues proposed in the Table 3.

Table 3. The Sample of a Worksheet Plan for Ecological Issues in High School Sociology

Ecological Issues Title (Theme):

Please look back at your ecological issues plan worksheet developed at the beginning of the semester and discuss the following questions in light of the progress made up to this point in the semester. The intention of this mid-semester meeting is to give everyone a chance to get together and talk about how things are going in your classes.

1. Given the original theme of your ecological issues, what do you reason has chosen it?

2. In what ways have your classes been integrated this theme on sociology course? How successful do you feel these integrations have been? What are you planning for the future (example: visiting classes, team teaching, assigning the same reading, same writing assignment)?

3. If there is a student seminar attached to your classes, in what way has the ecological issues been incorporated into the sociology learning? How has this incorporation worked in terms of advancing the goals and curricular theme of your classes?

4. In what ways, if any, have your student demonstrated knowledge that they are part of a ecological issues (examples: direct reference to the ecological issues, use of materials from other classes, references to other teachers or experts)?

5. Are there students that need additional help or support in doing well in your classes? If any, in what ways has the ecological issues been explored within sociology learning?

6. What have the ecological issues done to facilitate cross-disciplinary learning in the classes? What other things could the students do?

Source: Table designed by author.

To develop the above ideas into a coherent document, teachers can arrange it in a learning plan is integrated with the green school programs or "Adiwiyata" school. Teachers should get in the habit of examining the discussion that is used in sociology classroom, and the everyday interactions in schools, and as much as possible, invite students into that examination. Ask students to identify what is hidden and illuminated in a metaphor and what the consequences of the hidden meanings are on ecological issues.

\section{Conclusions}

Drawing on the work of content analysis from the handbook of education for sustainable development in Indonesia, the Ministerial Regulation about implementation of the green-school or 'Adiwiyata' school, the development guidelines of environmental education content, and four documents curriculum of the high school sociology, this article offer the following four interrelated elements to teaching sociology for high school students within ecological issues: 
1. An approach to pedagogy and curriculum development that emphasize both deep sociological analysis and community-based learning encouraging students to identify the causes and remediate the effects of social an ecological violence in the place where we live.

2. Think differently about our relationships to each other and to the natural world, through teaching students to identify and revalue those critical practices of mutual support and interdependence that still exist in communities all over the world

3. Ecopedagogy is a growing scholarly field that applies basic principles of critical pedagogy to the study of intersecting social and ecological issues.

4. Ecopedagogy approach calls for rethinking what citizenship means, what it means to be educated for citizenship, and what the purposes of public schooling ought to be.

As a recommendation, needed a model of teaching sociology that rooted on eco-pedagogy for developing students' ecological intelligent. In order to embrace this type of proposal, teacher must take action and model it in their classroom. Students should be given the opportunity to take action related to the context they are learning in as it relates to their communities through praxis. Embracing ecopedagogy praxis into education is a meaningful way to make learning more relevant to our youth, while empowering students to move towards peaceful and just healthy communities.

\section{References}

Antunes, A., \& M. Gadotti. (2005). Eco-pedagogy as the Appropriate Pedagogy to the Earth Charter Process. In P. Blaze Corcoran (Ed.), The Earth Charter in Action: Toward a Sustainable World. Amsterdam: KIT Publishers.

Apple, M.W. (2004). Ideology and Curriculum. New York and London: RoutledgeFalmer.

Atkinson, M.P. \& Lowney, K.S. (2016). In the Trenches: Teaching and Learning Sociology. New York \& London: W.W. Norton \& Co.

Atkinson, M.P. (2000). The Future of Sociology is Teaching? A Vision of the Possible. Contemporary Sociology, 29, 329-332.

Arnawa, I.K., Sukerta, I.M., \& Limantara,L.M. ( 2018). Preservation Model for Subak in Bali from Environmental Economics Perspective. International Journal of GEOMATE, 15(52), 238-243.DOI: https://doi.org/10.21660/2018.52.78348.

Burawoy, M. (2005). For Public Sociology. American Sociological Review, 70, 4-28.

Burawoy, M. (2013). Public Sociology: The Task and the Promise. In Gould, K.A \& Lewis, T.L. Ten Lessons in Introductory Sociology. USA: Oxford University Press. Pp. 278-298.

DeCesare, M. (2007). A Discipline Divided: Sociology in American High Schools. UK: Lexington Books.

Desha, C., \& Hargroves, K.C. (2014). Higher Education and Sustainable Development: a Model for Curriculum Renewal. London \& New York: Routledge.

ECORYS. (2010). Programmes to promote environment skills. Rotterdam: ECORYS Nederland BV.

Elbaar. E.F., \& Limantara, L.M. (2019). Local Wisdom in Capture Fisheries Activity in Sabangau Area, Central Kalimantan. International Journal of GEOMATE, 16(53), 78-85.

DOI: https://doi.org/10.21660/2019.53.40936

Freire, P. (2005). Pedagogy of indignation. Boulder, CO: Paradigm Publishers.

Gadotti, M. (2010). Reorienting Education Practice Towards Sustainability. Journal of Education for Sustainability, 4(2), 203-211.

Gans, H.J. (2016). Public Sociology and its Publics. The American Sociologist, 47(1), 3-11.

Giroux, H.A. (1988). Teachers as Intellectuals: Toward a Critical Pedagogy of Learning. Massachusetts: Bergin \& Garvey Publishers, Inc.

Hartmann, D. (2016). Sociology and Its Publics: Reframing Engagement and Revitalizing the Field. The Sociological Quarterly. 2016 Midwest Sociological Society Presidential Address. DOI https://doi.org/10.1080/00380253.2016.1248132 
RedWhitepress Global Conferences Series: Social Sciences, Education and Humanities (GCSSSEH), Volume 3, 2019

Hayward, B. (2012). Children, citizenship and environment: Nurturing a democratic imagination in a changing world. London: Routledge.

Jeffries, V. (2009). Redefining the Nature and Future of Sociology: Toward a Holistic Sociology. In Vincent Jeffries (ed.), Handbook of Public Sociology. UK: Rowman \& Littlefield Publishers, Inc.

Kennedy, K.J., \& Chow,J.K.F. (2013). Schooling's Contribution to a Sustainable Future in Asia: Can Schools Develop 'Green' Citizens? In R. Maclean et al. (eds.), Skills Development for Inclusive and Sustainable Growth in Developing Asia-Pacific, Technical and Vocational Education and Training: Issues, Concerns and Prospects 19, DOI 10.1007/978-94-007-5937-4_19. Asian Development Bank. London and New York: Springer.

Khan, R. (2010). Critical Pedagogy, Ecoliteracy and Planetary Crisis: The Ecopedagogy Movement. New York: Peter Lan.

Krippendorff, K. (2013). Content Analysis: An Introduction to Its Methodology (3 ${ }^{\text {rd }}$ ed.). Sage Publications, Inc.

Martusewicz, R.A., Edmundson, J., \& Lupinacci, J. (2011). EcoJustice Education: toward Diverse, Democratic, and Sustainable Communities. New York \& London: Routledge.

McLaren, P. (2013). Seeds of Resistance: Towards a Revolutionary Critical Ecopedagogy. Socialist Studies, 9(1), 84-108. doi: 10.18740/S4QG6G.

Mezirow, J. (1991). Transformative Dimensions of Adult Learning. San Francisco: Jossey-Bass Publishers.

Misiaszek, W. (2011). Ecopedagogy in the Age of Globalization: Educators' Perspectives of Environmental Education Programs in the Americas which Incorporate Social Justice Models. Dissertation. Los Angeles: University of California.

Neuendorf, K. A. \& Kumar, A. (2015). Content Analysis. The International Encyclopedia of Political Communication (1st ed). Edited by Gianpietro Mazzoleni.

DOI: 10.1002/9781118541555.wbiepc065.

Nikolopoulou, A., Abraham, T., \& Mirbagheri, F. (2010). Education for Sustainable Development: Challenges, Strategies, and Practices in a Globalizing World. India: Sage Publications.

Norat, M., Herreria, A.F., \& Rodriguez, F.M. (2016). Ecopedagogy: A Movement between Critical Dialogue and Complexity: Proposal for a Categories System. Journal of Education for Sustainable Development, 10(1), 178-195.

Rajaraman, J., \& Thiruvenkatasamy, K. (2013). Integrated Environmental Management for Sustained Development. International Journal of GEOMATE, 5(2), 735-742.

Roberts, K.A. \& Piker-King, K. (1995). Teaching Sociology in High School: A Guide for Workshop Organizers. Washington: American Sociological Association.

Schreier, M. (2012). Qualitative Content Analysis in Practice. Los Angeles, CA: Sage.

Seperson, S.B. (1994). What's Wrong with Sociology? Its Public Image. Sociological Forum, 10, 309-312.

Srikongphlee, V., Luvila, V., \& Kanato, M. (2018). Effectiveness of Life Skills Training and Promoting Family Environment to Prevent Youth Substance Abuse: a Study in Khon Kaen, Thailand. International Journal of GEOMATE, 15(50), 88-94. DOI: https://doi.org/10.21660/2018.50.3581

Thorpe, D. (2018). Meeting the Challenges of Engineering a Sustainable Future. International Journal of GEOMATE, 14(43), 8-18. DOI: https://doi.org/10.21660/2018.43.key2

Watson, B.A. (1955). Sociology in the High School. Sociology and Social Research, 39, 177-178. 